\title{
An Examination of the Acceptability of OET to the Potential Nurses From College of Nursing, Kuantan, Malaysia
}

\author{
J. Jebunnesa and Abdullah B. Ibrahim \\ Faculty of Technology, Universiti Malaysia Pahang, Malaysia
}

\begin{abstract}
The growth of culturally and linguistically diverse population in Malaysia has led to many efforts to encourage or ensure that health care systems respond to the distinct needs of culturally and linguistically different patients by becoming "culturally competent". So the implementation of OET will play an increasingly expedient role both in medication and in medical tourism. Occupational English Test is an English language proficiency test for health practitioners intending to check whether health practitioners have sufficient knowledge of English to be used in job-related context. It is designed by Professor Tim Mc Namara under contact with Australian Federal Government and is used by Australia, New Zealand and Singapore. This study using a case study method intends to know the acceptability of OET in Malaysia. The objectives of this study are to assess Malaysian nurses' performance in the existing OET writing test and to know their attitude towards the test. The cases are 31 nursing students from a reputed nursing college in Kuantan, Malaysia. The researcher administers some sample OET writing test questions on the cases at first so that they can have a clear idea about OET and after the test, she interviews 5 cases individually to know their view in detail. The researcher analyzes the result manually. From the test and especially from the interviews, it comes out that OET is very much acceptable to the nurses and though most them are not good in grammar, their performance in test is satisfactory on average because the task is associated with their job.
\end{abstract}

Key Words: OET, nurses, medical, language, Kuantan

\section{Introduction}

OET is a profession-centered course, utilizing the language of specific health professions, and therefore a more natural test of English proficiency for overseas health professionals to use than IELTS. The OET is administered by the OET Centre up to ten times a year and in over 40 locations around the world. The Test assesses the language proficiency of health practitioners who are seeking registration and the ability to practice in an English-speaking context. It is designed to ensure that language competency is assessed in a relevant professional context.

The language testing for nurses and other medical practitioners may be different from that of other professionals. Professional English for medical practitioners involve a wide variety of medical vocabulary. These include diseases and symptoms, investigations, treatment, examining and prevention. These also include general medical vocabulary related to parts and functions of the body, medical and para-medical personnel, education and training, research, and presentations. The testing of the medical practitioners should be suitable to their working contexts.

OET has been playing an increasingly important role in facilitating nurses' preparation for professional requirements, training and study. Nursing and medical work have many concepts, descriptions and terminology in English. Advanced study requires sufficient English ability in technical areas. Occupational English Testing for instance prepares students for such job related English as terminology and medical abbreviations that they will use in daily career task. Professional English used for medication contains a wide variety of medical vocabulary. Topics include diseases and symptoms, investigations, treatment, examining and prevention. These also include general medical vocabulary related to parts and functions of the body, medical and para-medical personnel, education and training, research, and presentations. Professional English used in Medicine has been carefully researched using the Institute for Applied Language Studies medical corpus and is a must for medical practitioners who need to use English at work, either in their own country or abroad, (Bradley, 2008).

Feeling secure of their knowledge and clinical expertise empowers nurses. By staying up-to-date with advances in their specialty, nurses can take pride in their expertise. Continuing education, specialty certification, and participation in professional organizations, clinical research, and conferences are good ways to stay in touch with developments in nursing field. Nurses should also establish informal collaborative work groups with other nurses where they can recognize and share their clinical expertise. Participating in 
interdisciplinary committees also empowers nurses to have an equal say in facility policies and procedures. Simply put, knowledge is power (Hughes, 2008).

\section{Material and Methods}

This study is a case study where the cases are 31 nursing students of Kolej Kejururawatan, Kuantan, Malaysia. The researcher mainly uses semistructured interview and also a questionnaire as primary data gathering instrument.

The secondary data are derived from related published documents. A questionnaire comprises of a set of tests which are revised from three OET sample writing test. The questionnaire is in English. It consists of three parts, cover page, section 1 and section 2 . The cover page of the questionnaire is used as an implied consent form. The cover page informs the samples that the information derieved from them will be kept confidential and be used only for academic purposes.

In section 1 of questionnaire, respondents are asked to write some basic information and section 2 contains three tests and the time for each test is 45 minutes, 5 minutes for reading and 40 minutes for writing.
The researcher interviews 5 nurses individually to know their opinion about OET. It is also appropriate because of "its flexibility balanced by structure and the quality of the data so obtained" (Gillham, 2005: 70). The researcher records and transcribes the interview answers for using those as data. Before the interview, the researcher administers the test so that the respondents can have enough idea about OET and they can opine effectively. Besides, all the respondents are adults and participation in the test and in the interview is voluntary.

\section{Results and Discussion}

On $5^{\text {th }}$ October, a writing test was administered on 31 nursing students of College of Nursing, Kuantan. The test was taken in pintu 1, kulliah 7. The nurses were from semester 2. After the writing test, 5 nurses were also interviewed individually. The writing test started at $2.00 \mathrm{pm}$ and ended at $4.25 \mathrm{pm}$. The test question included three tests which were revised from three sample writing tests of OET based on the pilot test. The Respondents had to write three referral letters based on some biological case notes of patients. As the samples are many in number, we can rate the samples' performances on four scales for our convenience. The scales are described in Table 1.

Table 1. Assessment scale for the writing test.

\begin{tabular}{|c|c|c|c|}
\hline Scale & Content & Grammar & Format \\
\hline Excellent & $\begin{array}{l}\text { Intensely well } \\
\text { organized and developed }\end{array}$ & $\begin{array}{l}\text { Excellent command of } \\
\text { grammar }\end{array}$ & $\begin{array}{l}\text { Very effectively } \\
\text { formatted }\end{array}$ \\
\hline Good & $\begin{array}{l}\text { Well organized and } \\
\text { developed }\end{array}$ & Good command of grammar & Effectively formatted \\
\hline Average & $\begin{array}{l}\text { Satisfactorily organized and } \\
\text { developed }\end{array}$ & $\begin{array}{l}\text { Basic knowledge of } \\
\text { grammar }\end{array}$ & $\begin{array}{l}\text { Basic knowledge of the } \\
\text { format }\end{array}$ \\
\hline Poor & $\begin{array}{l}\text { Disorganized and not } \\
\text { developed }\end{array}$ & $\begin{array}{l}\text { Great difficulty in writing } \\
\text { accurate sentence }\end{array}$ & $\begin{array}{l}\text { Limited elements of format } \\
\text { are found }\end{array}$ \\
\hline
\end{tabular}

The researcher assesses the test takers' performances based on the following ratings. As the researcher wants to keep the information of the samples confidential, she names them as Respondent 1, 2, 3..... and the like. Now individual test score and average of three test scores in a table. The score of the test which is not answered will be considered as poor. Table 2 will arrange individual and average score of the respondents. From the Table 2, it is noticed that students answered very spontaneously. Though they had to answer three tests at a time, only 3 students escape 1 and 2 students escape 2 tests among 31 students. Their performance is also satisfactory. Among 31 students 10 students get poor, 2 students get good and the remaining 19 get satisfactory score on average. We see that most of the students' grammar is not good but they score average in the tests because to answer the test they not only need language knowledge but also need content knowledge. 
Table 2. Scores of the respondents from College of Nursing.

\begin{tabular}{|c|c|c|c|c|}
\hline Respondent No: & Score in test 1 & Score in test 2 & Score in test 3 & Average Score \\
\hline Respondent 1 & Good & Poor & No answer & Average \\
\hline Respondent 2 & Average & Average & Poor & Average \\
\hline Respondent 3 & Poor & Poor & Poor & Poor \\
\hline Respondent 4 & Average & Average & Average & Average \\
\hline Respondent 5 & Average & Average & Average & Average \\
\hline Respondent 6 & Average & Average & Average & Average \\
\hline Respondent 7 & Good & Average & Average & Average \\
\hline Respondent 8 & Average & Good & Good & Good \\
\hline Respondent 9 & Average & Average & Poor & Average \\
\hline Respondent 10 & Average & Poor & Poor & Poor \\
\hline Respondent 11 & Average & Poor & Poor & Poor \\
\hline Respondent 12 & Average & Poor & Poor & Poor \\
\hline Respondent 13 & Average & Average & Average & Average \\
\hline Respondent 14 & Average & Average & Average & Average \\
\hline Respondent 15 & Poor & Poor & Poor & Poor \\
\hline Respondent 16 & Average & Poor & Poor & Poor \\
\hline Respondent 17 & Average & Average & Average & Average \\
\hline Respondent 18 & Average & Average & Average & Average \\
\hline Respondent 19 & Average & Average & Average & Average \\
\hline Respondent 20 & Good & Average & No answer & Average \\
\hline Respondent 21 & Good & Good & Good & Good \\
\hline Respondent 22 & Average & Good & Average & Average \\
\hline Respondent 23 & Average & Average & Average & Average \\
\hline Respondent 24 & Average & Average & Average & Average \\
\hline Respondent 25 & Average & Poor & Poor & Poor \\
\hline Respondent 26 & Average & No answer & Poor & Poor \\
\hline Respondent 27 & Average & No answer & No answer & Poor \\
\hline Respondent 28 & Average & No answer & No answer & Poor \\
\hline Respondent 29 & Average & Average & Average & Average \\
\hline Respondent 30 & Average & Average & Average & Average \\
\hline Respondent 31 & Average & Average & Average & Average \\
\hline
\end{tabular}

In the interview also, all the students except one said that the tests are difficult to them and note forms are difficult for them to extend which also indicates their poor grammar. All the respondents pointed out that nurses' lack of communication skill can create many problems in medication and OET is suitable to assess their language proficiency. Above all, nurses through their spontaneous response and in the interview express that OET is acceptable to them. They also opined that their grammar, vocabulary, speaking and other language ability should be tested as their communicative ability is associated with patient safety.

\section{Conclusions}

The result of this study which is conducted by OET sample writing test and especially the interviews obviously signify that nurses' lack of communication is a barrier to patient safety. Therefore their language proficiency needs to be tested and OET is suitable for this purpose because OET exemplifies the real difficulty of language performance of health practitioners in work-related environment. All the nurses in the interview opine that OET is suitable to be used in Malaysia. Highly skilled nurses, being a part and parcel of healthcare team, are always in good demand locally and globally. By implementing OET on the nurses, Malaysia can produce highly skilled and linguistically competent nurses who can mitigate the risk of health services due to in adequate English language skills and can also work in abroad.

\section{Implications}

This study furnishes empirical data on a certain group of nurses from a nursing college in Kuantan. The aim is to assess the acceptability of OET to the potential nurses from College of Nursing or to Malaysian nurses but this study does not yet cover the entire wide spectrum of the OET process and the whole Malaysian nurses. This study finds (interview) that OET is very much acceptable to the nurses of College of Nursing. However, it is important to investigate the same thing as perceived by other students from other medical institutions to see how these perceptions reconcile with the findings of this study. 


\section{References}

Bradley, R. A. (2008). English for Nursing and Health Care. Singapore: Mc Graw-Hill.

Fortier, J.P., Convissor, R., \& Pacheco, G. (1999). Assuring cultural competence in health care: Recommendations for national standards and an outcomes-focused research agenda. Washington, DC: Department of Health and Human Services and Resources for Cross Cultural Health Care.
Stake, R. (1995). The art of case study research (pp. 49-68). Thousand Oaks, CA: Sage.

Hughes, R. G. (ed.). Patient safety and quality: An evidencebased handbook for nurses. (Prepared with support from the Robert Wood Johnson Foundation). AHRQ Publication, No. 08-0043. Rockville, MD: Agency for Healthcare Research and Quality; March 2008.

Gillham, B. (2005). Research Interviewing: The Range of Techniques (pp. 70.). USA: Open University Press. 